\title{
AN ANALYSIS OF WORD FORMATION ENCOUNTERED IN MEDICAL TERMS IN THE JAKARTA POST'S ARTICLES
}

\author{
Nurlin Triwahyuni \\ University of Bengkulu \\ Nurlinnuy@gmail.com \\ Imranuddin \\ University of Bengkulu \\ Imranulama@gmail.com \\ Zahrida \\ University of Bengkulu \\ Zahridaadnan@gmail.com
}

\begin{abstract}
The aim of this research was to find out the types of word formation in medical terms in The Jakarta Post's health articles. This research was designed as a descriptive qualitative research. The population of this research was all medical terms in The Jakarta Post newspaper. The sample of this research was medical terms found in seven health articles in The Jakarta Post newspaper which published from June until December 2016. Documentation was used as main instrument in this research. There were 10 types of word formation by Yule (2010). The result of this study showed, there are 55 data of derivation, 20 data of compounding, 16 data of borrowing, 11 data of acronym, 2 data of clipping, and one data of backformation. It can be concluded, there are six types of word formation were found in seven health articles. Further, there is no coinage, blending, conversion, and multiple processes were found in medical terms in seven health articles in The Jakarta Post's newspapers.
\end{abstract}

sKeywords: Word Formation, Medical Terms

\section{INTRODUCTION}

People and communication are two words that cannot be separated. As long as human live, they need to communicate to each others. They communicate for different purpose. It can be said, people communicate each other to fulfill their needs. To communicate, human beings need "a tool" to deliver their ideas, it is known as language. According to Wibowo (2001), language is a system of symbols that are meaningful and articulate sound (generated by said tool) which arbitrary and conventional, which is used as a means of communicating by group of human being to give birth to feeling and thoughts. In short, language is a tool to interact with other people to convey or express their needs, feelings, and thoughts.

Language cannot be separated with the term of linguistics. Lyons (1968) defines linguistics as the scientific study of language by means of controlled and empirically verifiable observations with reference to some general theory of language structure. In other words, 
linguistics is a scientific study of language and its structure, its meaning, and its context. Linguistics are divided into some subfield, they are phonology which studies of speech sounds, syntax which studies of sentences, semantics which studies of meaning, pragmatics which studies of language use, and morphology which studies of internal structures of words.

Morphology is a branch of linguistics. Morphology refers to the study that deals with internal structure of the words in a language. According to Gleason (1970), morphology is the description of the more intimate combination of morpheme, roughly what are familiarly called "words". A morpheme means the smallest grammatical unit that cannot be separated into smaller meaningful parts. Morphemes can be divided into two; they are free morpheme and bound morpheme. Free morphemes are independent words, whereas bound morphemes are dependant words that need other morphemes to create meaningful words. Some of the morphemes combine with other morphemes to form new words in a language. This process is called word formation.

Word formation is one of the concerns in morphology field, which discusses about the ways new words are created in the language. It means most of the languages have the ways or the processes in create words, including English. In English, there are some theories about types of word formation process by the linguists.

As the impact of globalization era in all over the world, most of the countries use English, including Indonesia. English as a language is not only used as speaking language, but also in written. Written language is representation of spoken language by using instruments and materials, such as pen, paper, and computer. Written language can be found in many kinds of mass media, for example, magazines, and newspapers.

In Indonesia, newspaper is kind of mass media which is popular for common people. According to Merriam-Webster Online Dictionary, newspaper is a paper that is printed and distributed usually daily or weekly that contains news, articles of opinions, features, and advertising. Almost everyone reads newspaper to get information. Newspaper has many functions for human beings. It can give a lot of information of current issues around the world, such as in the field of politics, economic, education, sports, entertainment, technology and also health In Indonesia, many newspapers have been publishing, both national and region. One of popular newspapers in Indonesia is The Jakarta Post.

The Jakarta Post is the daily newspaper that uses English as language to communicate to the reader. This newspaper is owned by PT. Media Tenggara (Wikipedia). The Jakarta Post has won several awards and been described as being "Indonesia leading English language daily", because This newspaper the only one that use full English which publish every day. The award proves that The Jakarta Post is a good authentic material for doing analysis study, because the articles have accurate information. Beside of that, the targets of the readers are well-educated people from middle until advanced level who understands English.

The newspaper contains a lot of useful information for the readers, both current events in Indonesia and also around the world. It is written in the form of articles, and every article has different topics to discuss. One of the topics is about health 
that related to medical field. Those articles usually contain many special terms, known as medical terms. According to Wikipedia (2010), medical terminology is language used to precisely describe the human body including its components, processes, conditions affecting it, and procedures performed upon in the field of medicine. From the definition, medical terms are the words or terms which make up the field of medicine.

In reading the articles, the researcher found that health articles have own language that differ from language that common people use in ordinary life. Most of medical terms come from Greek and Latin language, and some of them use English or the joining or combining between Latin or Greek language and English. It means, there are rules or ways that are applied in forming the terms.

One of the example was found, not all the terms use single word or free morpheme, but most of terms are combined with other word or morpheme to form new words, such as in the term one of medical terms in the health article is "CT scan". Most of people commonly know the word "CT scan" as a medical check using $X$-rays that produce "image" inside human body, without knowing the exactly meaning of the word and the process that involved in forming the word. In morphology, especially in the study of word formation, there is a process of word formation is involved in that term. Actually, the word " $C T$ " means a Computer Tomography. This forming process is called acronym. Yule (2010) defines, acronyms are new words formed from the initial letters of a set of other words. These rules or ways are interesting to be investigated as a study, because every word has their own process that can be described.
Toward this phenomenon, Yule (2010) has proposed ten types of word formation. Those are coinage, borrowing, compounding, blending, clipping, backformation, conversion, acronym, derivation and multiple processes. Those types of word formation would lead the researcher to know the types of word formation that is used in medical terms, particularly in the health articles. These ten types of word formation have their definitions which different one and other. Coinage is a process of creating new term from trades names or commercial product that become general terms, for example Kleenex and aspirin. Borrowing is the process of actually borrowing word from foreign language, such as sofa from Arabic. Compounding is a joining of two words to produce a single form, for example fingerprint and wallpaper. Blending is the combination of two separate form by taking only the beginning of one word and joining it to the end of other words, for example brunch (breakfast/lunch). Clipping occurs when a word of more than syllable (influenza) is reducing to shorter form (flu). Backformation is reducing process from a word of one type (usually a noun) to form word another type (usually a verb), for example the noun television came first before the verb televise. While, conversion is changing the function of a word without any reduction, for example the word chair and butter. Acronym defines, new words formed from initial letters of a set of other words, such CD (Compact Disk), and VCR (Video Cassette Recorder). Derivation is a process when a word is created where its meaning and its category is distinct from it base by adding affixes, such as unhappy or joyful. The last type is multiple process; when a word is possible to trace operation more than one processes at work in 
particular word, for example the word "snowballed" there are two word formation are involved. First is compounding (snow + ball) and conversion (snowballed)

Due to the fact, the analysis of word formation in medical terms may have significant influence for Department English student, especially linguistic (morphology) students and also medical student. This study is interested to be investigated, so medical terms is considered as appropriate sample for this study entitled "An Analysis of Word formation Encountered in Medical Terms in The Jakarta Post's Articles". The aims of this study are to find out the types of medical terms in medical term in health articles and to explain how the medical terns are classified.

\section{METHOD}

This study was designed as descriptive qualitative research, specifically descriptive analysis study. According to Meleong (2009), the analysis in qualitative research, concern in understanding the result of found data rather than calculate the result of found data.

According to Arikunto (2002), population is a total subject of the research Population of this study was all medical terms in The Jakarta Post newspapers.. The samples in this research was medical terms found in seven health articles in The Jakarta Post newspapers published from June until December 2016. As Waito (1992) states, sample is a part of population taken to be representative of the population and it is actually the real data source of the study .

The instrument for collecting the data in this study was documentation According to Arikunto (2006), documentation method is a method where the researcher investigates the written things such as books, magazines, documents, diaries, etc. In this study, the document were seven health articles in The Jakarta Post newspaper from different editions (published from June until December 2016), which has been observed by researcher to identify the types of word formations of medical terms that is used According to Yule (2010). The data also used classification form and data cards as the supporting intruments.

In this study, technique of collecting data used some steps. First, the researcher adopted health articles from The Jakarta Post newspapers. Second, the researcher read the articles. Then, the researcher found out medical terms in the articles. After, the researcher got the data; the researcher put the data into classification form. After collecting the data, the next step was analyzing. The data in this research were analyzed by using descriptive analysis technique. In analyzing the data, this research took several steps. First was wrote down the description of the data (medical terms) on data card. Data cards use to identify the data from the seven health articles in The Jakarta Post newspaper based on each types of word formation. After the data description was written on data card, the researcher analyzed how the word formation process of each medical term classified by using Yule's theory (2010) and morphology concept.

\section{RESULT AND DISCUSSION}

Table 1. Total of the Data

\begin{tabular}{|c|c|c|c|}
\hline $\begin{array}{l}\mathbf{N} \\
\mathbf{0}\end{array}$ & $\begin{array}{c}\text { Types of } \\
\text { word } \\
\text { formation }\end{array}$ & Medical Terms & $\begin{array}{l}\text { To } \\
\text { tal }\end{array}$ \\
\hline & Coinage & - & - \\
\hline & Borrowing & $\begin{array}{ll}\text { 1. } & \text { Diagnosis } \\
\text { 2. } & \text { Therapeutic } \\
\text { 3. } & \text { Medication }\end{array}$ & 16 \\
\hline
\end{tabular}




\begin{tabular}{|c|c|c|}
\hline & $\begin{array}{ll}\text { 4. } & \text { Alcohol } \\
\text { 5. } & \text { Diabetes } \\
\text { 6. } & \text { Cough } \\
\text { 7. } & \text { Dose } \\
\text { 8. } & \text { Medicines } \\
\text { 9. } & \text { Influenza } \\
\text { 10. } & \text { Glucose } \\
\text { 11. } & \text { Supplement } \\
\text { 12. } & \text { Cancer } \\
\text { 13. } & \text { Cramps } \\
\text { 14. } & \text { Cells } \\
\text { 15. } & \text { Tumor } \\
\text { 16. } & \text { Lymph }\end{array}$ & \\
\hline Compounding & $\begin{array}{l}\text { 17. Uric-acid } \\
\text { 18. Lithotripsy } \\
\text { 19. Welfare } \\
\text { 20. Appendectomy } \\
\text { 21. Healthcare } \\
\text { 22. Oxygen } \\
\text { 23. Thrombolysis } \\
\text { 24. Physiotherapy } \\
\text { 25. Artery-wall } \\
\text { 26. Cardiocerebrova } \\
\text { scular } \\
\text { 27. Antibitic- } \\
\text { resistant } \\
\text { 28. Carbohydrates } \\
\text { 29. Radiotherapy } \\
\text { 30. Colorectal } \\
\text { 31. Biopsy } \\
\text { 32. Laparoscopy } \\
\text { 33. Gastroscopy } \\
\text { 34. Colonoscopy } \\
\text { 35. Endoscopy } \\
\text { 36. Chemotherapy }\end{array}$ & 20 \\
\hline Blending & - & - \\
\hline Clipping & $\begin{array}{l}\text { 37. } \\
\text { 38. } \text { Carbs }\end{array}$ & 2 \\
\hline $\begin{array}{l}\text { Backformatio } \\
n\end{array}$ & 39. Diagnosed & 1 \\
\hline Conversion & - & - \\
\hline Acronym & $\begin{array}{ll}\text { 40. } & \text { ESWL } \\
\text { 41. } & \text { BCSL } \\
\text { 42. } & \text { ICU } \\
\text { 43. } & \text { FAST } \\
\text { 44. } & \text { ER } \\
\text { 45. } & \text { JCl } \\
\text { 46. } & \text { WHO } \\
\text { 47. } & \text { GI } \\
\text { 48. } & \text { CT scan } \\
\text { 49. } & \text { MRI scan } \\
\text { 50. } & \text { PET scan }\end{array}$ & $\begin{array}{l}1 \\
1\end{array}$ \\
\hline Derivation & $\begin{array}{ll}\text { 51. } & \text { Incisions } \\
\text { 52. } & \text { Treatment } \\
\text { 53. } & \text { Non-surgical } \\
\text { 54. } & \text { Lithotripter } \\
\text { 55. } & \text { Urology }\end{array}$ & $\begin{array}{l}5 \\
5\end{array}$ \\
\hline
\end{tabular}

\begin{tabular}{|c|c|}
\hline & $\begin{array}{l}\text { 56. Urinary } \\
\text { 57. Extracorporeal } \\
\text { 58. Complication } \\
\text { 59. Anesthesia } \\
\text { 60. Analgesia } \\
\text { 61. Surgical } \\
\text { 62. Specialist } \\
\text { 63. Ultrasound } \\
\text { 64. Crystallization } \\
\text { 65. Perspiration } \\
\text { 66. Illnesses } \\
\text { 67. Operation } \\
\text { 68. Coronary } \\
\text { 69. Laboratory } \\
\text { 70. Hypertension } \\
\text { 71. Neurologist } \\
\text { 72. Neurological } \\
\text { 73. } \text { Blockage } \\
\text { 74. Intravenously } \\
\text { 75. Emergency } \\
\text { 76. Thrombolytic } \\
\text { 77. Physician } \\
\text { 78. Recurrence } \\
\text { 79. Indication } \\
\text { 80. Contraindication } \\
\text { 81. Extracranial } \\
\text { 82. Intracranial } \\
\text { 83. Non-invasive } \\
\text { 84. Smokers } \\
\text { 85. Alcoholics } \\
\text { 86. Antimicrobial } \\
\text { 87. Prescribe } \\
\text { 88. Prescription } \\
\text { 89. Prevention } \\
\text { 90. Chemicals } \\
\text { 91. Infection } \\
\text { 92. Blindness } \\
\text { 93. Diabetic } \\
\text { 94. Nutritional } \\
\text { 95. Insulin } \\
\text { 96. Supplementation } \\
\text { 97. Digestive } \\
\text { 98. Internist } \\
\text { 99. Screening } \\
\text { 100. Detection } \\
\text { 101. Irritation } \\
\text { 102. Abdominal } \\
\text { 103. Malignant } \\
\text { 104. Diagnostic } \\
\text { 105. Metastasized }\end{array}$ \\
\hline $\begin{array}{l}\text { Multiple } \\
\text { Process }\end{array}$ & - \\
\hline \multicolumn{2}{|l|}{ Total: } \\
\hline
\end{tabular}




\section{Discussion}

According to Yule (2010), there are ten types of word formation; they are coinage, borrowing, compounding, blending, conversion, backformation, clipping, acronym, derivation, and multiple process.

From the data analysis of the seven health articles in The Jakarta Post newspapers, there was 105 data found; 55 derivations, 20 compounding, 16 borrowing, 11 acronyms, two clippings, and only one backformation.

There was 55 data that have been identified as derivation. It means most of medical terms encountered in Medical Terms in the seven health articles in The Jakarta Post newspaper use derivation process in building the terms. These parts contain at least three parts; they are root, prefix, and suffixes. As the theory from Stanfield et al., (2007); they said that, there are three basic parts of medical terms; they are prefixes, word roots, and suffixes. The root brings the essential meaning of the word, while prefixes and suffixes are attached to the root to make the terms more specific or to modify the basic meaning.

The findings of the study showed that there are the process of changing the word classes, because the roots of these terms has been attached by prefixes or suffixes. Any kind of affixes that can change the word class is known as derivational morphemes. As Yule (2010) claims, derivational morpheme are used to make new words or to make of a different grammatical category from the stem. It is include suffix and prefix.

According to Rozelin (2012), there are nine types of word class in English. In this analysis there are eight of them. First, there are 17 data of derivation change the word class from verbs into nouns. Most of the category of word changes verbs into nouns, because in the health articles describe actions or condition. It characterized by some kinds of suffixes, such as -ion in the term indication, -ation in crystallization, -ence in recurrence, -er in smokers, -ing in screening, and -ment in treatment. Second, there are 13 data change the word class from nouns into adjectives. It is characterized by some suffixes, such as $-a l$ in surgical, -ic in diabetic, -ary in urinary. Third, there are 5 data change the word class from adjectives into nouns. It is characterized by some suffixes, such as -ist in internist, and -ness in blindness. There are 2 data change the word clas from verbs into adjective. It is characterized by some suffixes, such as -ive in digestive, and -ant in malignant. Then, there are two data change the word class from nouns into verbs. It is characterized by some affixes, such as the prefix pre- in prescribe, and the suffix -ize in metastasized. The last is one data changes the word class from an adjective into an adverb that modify by affixes; a prefix intra- and a suffix $-l y$ in intravenously.

Beside of that, there are some data do not change the word class, but they change the meaning of the root by some affixes. This finding showed, there are 16 data do not change the word class, they just transform the meaning. The kind of affixes that change the word class known as inflectional morphemes.

The second type found in medical terms is compounding. There are 20 data found that are identified as compound words. From 20 data, there are 19 data are identified as compound nouns. Compound noun often use in medical articles, especially these seven health articles, some of medical terms combine two word to produce a single terms to describe and explain the name of 
treatments such as endoscopy and laparoscopy, the name of disease, such as uric-acid, and also the human's body parts such as artery-wall. It occurs because a single term perhaps does not enough to describe something; it needs other term to complete it.

The third type found in medical terms is borrowing. There are 16 data showed the borrowing process. From the data finding, it can be concluded that some of medical terms adopted from other language. In this case, most of medical terms adopted from Greek and Latin, such as in the term diabetes 'diabenein', glucose 'gleucose', medicine 'medicus'. And cell 'cella'. This phenomenon occurs because the scientific from Greek develop the head of knowledge, especially medical field. The impact of the development of medical field around the world, it makes some of medical terms also adopted from modern language. This study found there some medical terms adopted from modern language, such the term influenza is from Italian 'influenza', the term cramp from Dutch 'krampe', the term alcohol from Arabic 'al-kuhl', and the term cough from German 'keuchen'.

Another type of word formation found in medical terms in seven health articles is acronym. There are 11 data has been identified as acronym. The acronym words, especially in medical terms are used to compact the meaning; to make the meaning more solid, so it will be easy to remember, especially for common people. In this study some of acronym words used to describe a treatment to cure people by machine or modern technology, such as CT scan and MRI scan, to describe the important room in hospital, such as ICU (Intensive Care Unit), and ER (Emergency Room), and some of acronym words used to compact the meaning of organizations, such as $\mathrm{WHO}$ (World Health Organization) and $\mathrm{JCl}$ (Joint Commission International).

The fifth type of word formation found in medical terms is clipping. There are only two clipping forms found, they are flu and carbs. Both of them sound familiar for people and they often use them for daily conversation. In the seven health articles, there are only two terms, because health articles in newspaper are written by using formal speech. It avoids miscomprehension for the readers. In linguistics, the clipping forms usually use in informal speech.

The last type found is backformation. There is only one datum of backformation; the term diagnosed. The term diagnose is back-formation from diagnosis. This process occurs when the word diagnosis came first into use, and then a verb diagnose is created from it.

Further, there is no coinage, blending, conversion, and multiple processes found in creating the medical terms in this research. It gives an assumption that most of the medical terms do not have those types of word formation. Another assumption is most of medical terms have derivation process in creating new terms. It can be proved the theory from Stanfield et al., (2007). They said that, there are three basic parts of medical terms; they are prefixes, word roots, and suffixes. Prefix is the word or element attached to the beginning of a word root to modify the meaning, but not all of medical terms have a prefix, while word root is core part of the word that has core meaning of the word root. By adding prefixes or suffixes, the meaning of the word is changed. The last part is suffix which has a meaning as the word part or element attached to the end of the wood root to modify its meaning. 
Medical terms also can be divided into some functions of words. In medical field, the medical terms can be classified into sub classification, first is related to the disease, second is related to medicines, and the last id related to physical (body). The term related to diseases consist of 32 data, such as hypertension, cancer, influenza, and cramp. The term related to medicines consist of 31 data, such as antibiotic-resistant, anesthesia, analgesia, and antimicrobial. The last is the term related to physical (body) consist of 10 data, such as extracranial, intracranial, artery-wall, and extracorporeal. The data that is not including into these three sub types of medical terms is categorized as linguistic terms.

From this result, this study has similar finding to the a study conducted by Meisara (2004) which found most of medical terms in New York Times's magazines have derivation process in creating new terms. The other types of word formation found in Meisara's study were compounding, abbreviation, and acronym. This study also used supporting theory from Rozelin (2011) about the several types of word class in English that also used by Meisara (2014). This present findings found 38 data change the category of words and 16 data maintain the category of word, whereas Meisara (2014) found there were eight data change the word class and three data maintain the word class (from sample data).

Meanwhile, this present findings are different to the other study findings, including a study conducted by Ismiyah (2015). Although, this study use same theory of word formation by Yule, but there were some differences. This study found all of the types of word formation by Yule and it found borrowing mostly used in forming business terms in The Jakarta Post newspaper. The other studies are conducted by Rustamaji (2015) and Hanif (2015) that also had different result to this finding. Both of these studies found compounding were mostly used in forming the word.

The result of several studies mentioned above could be different because the object of the studies is different each others. The other reason, in analyzing the data, the previous studies used different theories, especially the theory about the types of word formation.

\section{CONCLUSIONS AND SUGGESTIONS}

According to Yule (2010), there are ten types of word formation. They are coinage, borrowing, compounding, blending, conversion, backformation, clipping, acronym, derivation, and multiple process. From the data analysis, there six types of word formation encountered in medical terms in seven heath articles in The Jakarta Post newspaper. They are compounding, borrowing, clipping, acronym, backformation, and derivation. Further, there is no coinage, blending, conversion, and multiple processes found in creating the medical terms in this research

From 105 data found, there are 55 data has been identified as derivation which means most of medical terms has derivation in building the terms. Derivation processes change the word classes. Most of them change the word class from a verb into a noun. It can be concluded that prefixes and suffixes are attached to the root can change the meaning of the word.

Then, it followed with other types; they are 20 data of compounding where most of them are compound nouns. There are 16 data of borrowing. Most of them 
are adopted from Greek and Latin, while the rest is adopted from modern language, such as Dutch, German, and Arabic. There are 11 data of acronyms. Most of the acronym words are derived from English, such ICU and WHO. Then, there are two data of clipping; flu and carbs. Both of them are familiar for common people, not only in medical field. The last type is backformation. There is only one backformation, where the noun diagnosis is came first before the verb diagnose.

From data findings, there are three sub-classifications of medical terms. The most dominant type is medical terms related to medicine, such as chemotherapy, colonoscopy, antibiotic, blindness, malignant and antimicrobial. The second dominant is medical terms related to diseases, such as hypertension, influenza, cough, and tumor. The less dominant is medical terms related to physical (body), such as intracranial, artery-wall, and abdominal.

The analysis of word formation related to words, language, and human life. Since, language is abstract element; it always changes time to time. Every field related to words that have diffrent ways in building the term, so it necessary to do further analysis about word formation to increase knowledge and understanding about language. Therefore, it is suggested to further researcher to analyze about word formation with different terms from other fields, such as in the field of economic, politic or law. The further studies also can use different theories to compare the result with these present findings.

\section{REFERENCES}

Arikunto, S. (2006). Prosedur Penilitian: Suatu Pendekatan Praktik. Jakarta: PT. Rineka Cipta.

Collin, P. (2005). Dictionary of Medical Terms ( $4^{\text {th }}$ ed.) . London: Bloomsbury Publishing Plc.

Gleason, H. A. (1980). An Introduction to Descriptive Linguistic, New York: Holt, Rinehart and Winston Inc.

Hanif, F. (2015). The Analysis of Word Formation of Soccer Terms in The Jakarta Post's Articles. Jakarta: UIN Syarif Hidayatullah.

Islamiyah. (2015). Word Formation Process in Bussines Section, Jakarta Post. Surabaya: UIN Sunan Ampel.

Meisara, R. (2014). Word Formation on Medical Terms in New York Magazine's Articles. Jakarta: UIN Syarif Hidayatullah.

Moleong, L. J. (2009). Metode Penelitian Kualitatif. Bandung: PT. Remaja Rosdakaya.

Newspaper. (n.d.). In Merriam-Webster's online dictionary. Retrived from https://www.merriam webster.com/dictionary/newspaper.

Rozelin, D. (2011). Derivasional dan Infleksional Bahasa Inggris. Fakultas Adab IAIN Sulthan Thaha Saifuddin Jambi, 26(4).

Rustamaji, E. (2015). Process of English Word Formation Found in Advertisement Boards in Kendal Regancy. Semarang: Universitas Negeri Semarang.

Stanfield, P.S ., Hui, Y.H., \& Cross, N. (2007). Essesntial Medical Terminology ( $3^{\text {rd }} \quad$ ed.). Massachusetts: Jones and Bartlett. 
Wasito, H. (1992). Pengantar Metodologi Penelitian. Jakarta: Gramedia Pustaka Utama.

Wibowo, W. (2001). OTONOMI BAHASA 7 Strategi Tulis Pragmatik Bagi Praktisi Bisnis dan Mahasiswa. Jakarta: Gramedia Pustaka Utama.

Wikipedia. (n.d.). Hippocrates. Retrived July 6, 2016 from https://en.wikipedia.org/wiki/Hippo crates

Wikipedia. (n.d.). Medical Terminology. Retrived December 4, 2016 from https://en.wikipedia.org/wiki/Medic al_terminology.

Wikipedia. (n.d.). The Jakarta Post. Retrived December 3, 2016 from https://en.wikipedia.org/wiki/The_J akarta_Post.

Yule, George. (2010). The Study of Language $\left(4^{\text {th }}\right.$ ed.). Cambridge: Cambridge University Press. 